\title{
Interleukin-10 Prevents Spontaneous Death of Germinal Center B Cells by Induction of the bcl-2 Protein
}

\author{
Yves Levy and Jean-Claude Brouet* \\ Department of Immunopathology, Hôpital Henri Mondor, 94000 Créteil, France; and * Laboratory of Immunopathology, \\ Research Institute on Blood Diseases, Hôpital Saint-Louis, 75475 Paris Cedex 10, France
}

\begin{abstract}
In this study, we show that IL-10 enhances in vitro the viability of purified splenic B cells. There was a two- to threefold increase in recovery of viable cells during a 15-d culture period in the presence of IL-10. This effect was abolished by neutralizing antibodies to IL-10. The survival of large splenic B cells, which mostly represent follicular center cells, was similarly increased. The in vitro rescue from spontaneous death of the latter cells is known to involve a bcl-2-dependent pathway. We therefore investigated whether IL-10 might affect bcl-2 expression. Unseparated B cells as well as large splenic B cells displayed a strong expression of bcl-2 protein by immunofluorescence at days 2-7 of culture in the presence of $\mathbf{I L - 1 0}$. Other lymphokines such as IL-2 and IL-4 were able to trigger only a transient and faint expression of bcl-2; moreover, this effect was abolished by anti-IL-10 mAb. Inasmuch as activated B cells can produce their own IL-10, this lymphokine may play a crucial role in relieving from apoptosis those $B$ cells that encounter their antigen in B cell follicles. (J. Clin. Invest. 1994. 93:424428.) Key words: interleukin-10 • apoptosis
\end{abstract}

\section{Introduction}

IL-10 was described originally as a cytokine produced by $\mathrm{Th}_{2}$ cells that inhibits the synthesis of cytokines by $\mathrm{Th}_{1}$ clones $(1$, 2 ). This effect is mainly related to a downregulation of monocyte function via a decrease of cytokine synthesis and of class II antigen expression leading to poor antigen presentation $(3,4)$. In addition, IL-10 has been shown to exert its effects on other cell types by acting as a mast cell $(5)$ and $T$ cell growth factor $(6,7)$. On resting murine B cells, IL-10 upregulates class II antigen expression and enhances viability (8). No effect of IL10 on unstimulated human $B$ cells has been reported although this lymphokine is a potent costimulator for $\mathrm{B}$ cell proliferation and differentiation induced by triggering of antigen receptors and/or CD40 molecules (9).

Address correspondence to Professor J. C. Brouet, Laboratory of Immuno-pathology, Research Institute on Blood Diseases, Hôpital SaintLouis, 1, avenue Claude Vellefaux, 75475 Paris Cedex 10, France.

Received for publication 13 May 1993 and in revised form 30 September 1993.

J. Clin. Invest.

(C) The American Society for Clinical Investigation, Inc.

0021-9738/94/01/0424/05 \$2.00

Volume 93, January 1994, 424-428
We show here that IL-10 prevents the spontaneous death of human splenic B cells in vitro. This protective effect of IL-10 on splenic B cells is associated with the induction of the synthesis of the bcl-2 protein which is known to play a key role in the rescue of germinal center B cells from apoptosis (10), suggesting that this in vitro effect of IL-10 may be of physiologic significance.

\section{Methods}

\section{Cells}

Spleen samples were obtained from patients with idiopathic thrombocytopenic purpura undergoing therapeutic surgery. Mononuclear cells were isolated by Ficoll-Hypaque (Lymphoprep; Nyegaard, Oslo, Norway) gradient centrifugation. Enriched B cell preparations were obtained after $\mathrm{T}$ cell depletion by rosetting with 2-amino-ethyl isothiouranium bromide-treated sheep red blood cells (SRBCs). B cells were further separated in light or dense fractions on a discontinuous density gradient (Percoll; Pharmacia Inc., Uppsala, Sweden). Large cells were recovered at the $40-50 \%$ interface and small cells at $60 \%$. Surface $\operatorname{IgD}$ expression as assessed by indirect fluorescence was performed to control the efficiency of the separation procedure.

\section{Measurement of $B$ cell viability and proliferation}

B cells were cultured at $1.10^{6}$ cells $/ \mathrm{ml}$ in tissue culture tube (3033; Falcon Labware, Oxnard, CA) in RPMI 1640 medium supplemented with $10 \%$ FCS, antibiotics, and $2 \mathrm{mM}$ L-glutamine (Seromed, Berlin, Germany). Cell viability was estimated by trypan blue exclusion. For proliferation assays, B cells were cultured at $10^{5}$ cells/well in flat-bottom microtiter plates (6708; Nunc, Roskilde, Denmark) in $200 \mu \mathrm{l}$ of culture medium, and DNA synthesis was measured by pulsing cultured cells with $1 \mu \mathrm{Ci}=37 \mathrm{kBq}\left[{ }^{3} \mathrm{H}\right.$ ] thymidine $(5 \mathrm{Ci} / \mathrm{mmol}$ per well; $\mathrm{CEA}$ Instruments, Inc. Saclay, France) during the last $8 \mathrm{~h}$ of culture.

\section{Reagents and antibodies}

Recombinant-IL-2 $\left(5 \times 10^{4} \mathrm{U} / \mathrm{mg}\right.$; Boehringer Mannheim GmbH, Mannheim, Germany), r-IL-4 ( $\left.10^{7} \mathrm{U} / \mathrm{mg}\right)$; provided by J. Banchereau, Schering-Plough Corp., Dardilly, France), and r-IL-6 (Boehringer Mannheim $\mathrm{GmbH}$ ) were used at $1 \mu \mathrm{g}, 10 \mathrm{ng}$, and $1 \mathrm{ng} / \mathrm{ml}$, respectively. r-IL-10 and a neutralizing $\mathrm{mAb}$ to $\mathrm{r}-\mathrm{IL}-10(10 \mu \mathrm{g} / \mathrm{ml})$ were gifts of Dr. J. de Vries (DNAX, Palo Alto, CA). r-IL-10 (10 ${ }^{7}$ $\mathrm{U} / \mathrm{mg}$ ) was purified from transfected $\mathrm{CHO}$ cells.

Bcl-2 mAb was obtained from DAKOPATTS (Glostrug, Denmark) and was used as indicated. Antibodies to human mu chains (BPA2-1 mAb) coupled to Sepharose 4B beads (Pharmacia Inc.) were used at $10 \mu \mathrm{g} / \mathrm{ml}$. CD40 mAb donated by J. Banchereau (ScheringPlough Corp.) was used at $1 \mu \mathrm{g} / \mathrm{ml}$.

\section{Immunofluorescence analysis}

Detection of bcl-2 protein by immunofluorescence on fixed cells and $F A C S^{\varpi}$ analysis. B cells were recovered after different times of culture, were cytocentrifuged on slides allowed to dry for $30 \mathrm{~min}$, and were 
fixed in acetone for $10 \mathrm{~min}$. After three washes in PBS, cells were incubated for $45 \mathrm{~min}$ with $\mathrm{mAb}$ to bcl-2 protein diluted 1:20 (DAKOPATTS). Anti-mouse purified biotinylated IgG and streptavidinFITC (Becton Dickinson Immunocytometry Systems, Mountain View, CA) were used as second and third steps with a predetermined dilution. For each experiment, an isotype-matched negative control was performed.

For FACS ${ }^{\circledR}$ analysis, cells were fixed in $4 \%$ paraformaldehyde, washed, and permeabilized with saponin $0.1 \%$ in HBSS (Gibco Ltd., Paisley, Scotland ) supplemented with $0.01 \mathrm{M}$ Hepes buffer. All subsequent steps were performed as outlined above except that all washes contained $0.1 \%$ saponin. Fluorescent analysis was performed on a FACScan ${ }^{\otimes}$ (Becton Dickinson Immunocytometry Systems).

$I L-10$ protein expression. Using the same biotin-streptavidin-FITC assay, IL-10 was detected using the I.85 mAb obtained by I. Joab (Department of Hematology, Villejuif, France) on cells fixed with acetonemethanol $(\mathrm{vol} / \mathrm{vol})$ at $-20^{\circ} \mathrm{C}$ for $10 \mathrm{~min}$.

\section{Results}

IL-10 enhances B cell viability. Splenic B cells were cultured at a concentration of $1.10^{6}$ cells $/ \mathrm{ml}$ in culture medium alone or in the presence of $10 \mathrm{ng} / \mathrm{ml} \mathrm{r-IL-10}$. Cell viability was estimated during a 15-d period by trypan blue exclusion. In the presence of r-IL-10, a reproducible enhancement of cell viability was noted (Fig. 1). This protective effect of r-IL-10 on spontaneous B cell death was obvious at day 4 (90 vs $50 \%$ viable cells in the presence of IL-10 and medium alone, respectively) and was still significant at day 7 ( 50 and $30 \%$ viable cells). There was no increase in cell survival when a neutralizing antiIL-10 $\mathrm{mAb}(10 \mu \mathrm{g} / \mathrm{ml})$ was added to the cultures containing IL-10 (46 and $76 \%$ viable cells in the presence of anti-IL-10 $\mathrm{mAb}$ or irrelevant control $\mathrm{mAb}$ ). These latter data indicate that the enhanced survival of B cells was directly related to r-IL-10. In accordance with previous data (9), r-IL-10 did not induce $\mathrm{B}$ cells to proliferate or differentiate; there was no increase in $\left[{ }^{3} \mathrm{H}\right]$ thymidine incorporation at days 3 and $4(560$ and $300 \mathrm{cpm}$ in medium alone and in the presence of IL-10, respectively).

Splenic B cells comprise mostly cells from follicles and the marginal zone; germinal center cells $(\mathrm{GCC})^{1}$ differ by their phenotype and function from follicular mantle cells and were shown to undergo apoptosis when briefly cultured in vitro (11). We therefore separated splenic B cells according to their density. Small dense cells comprised mainly IgD-positive lymphocytes as expected for follicular mantle cells, whereas large light B cells were devoid of IgD expression as is characteristic of GCC. As shown in Fig. 1, the latter cells exhibited an increase in viability in the presence of r-IL-10. As expected, cells cultured in medium alone exhibited the nuclear condensation and fragmentation which characterize the apoptotic process.

$I L-10$ induces bcl-2 protein expression. The results of the above experiments suggested that r-IL-10 was able to prevent GCC from entering apoptosis. Since rescue of GCC from death is associated with synthesis of the protooncogene bcl- 2 protein in various models $(10,11)$, we examined by immunofluorescence its expression in r-IL-10-treated $\mathrm{B}$ cells after various times of culture. As shown in Fig. $2 A, \sim 30 \%$ of unseparated B cells expressed detectable levels of the bcl-2 protein. In contrast, most $B$ cells expressed bcl-2 protein when cultured in the presence of r-IL-10 at days 2-7 (Fig. $2 \mathrm{~B}$ ). Similar experiments

1. Abbreviation used in this paper: GCC, germinal center cells.

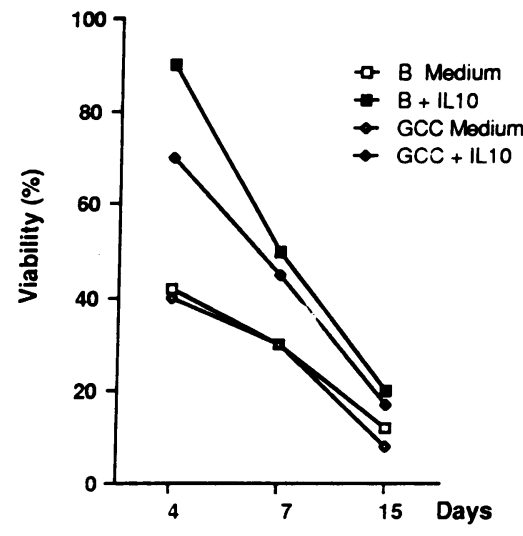

Figure 1. IL-10 enhances the viability of splenic B cells. Cell viability was assessed by trypan blue exclusion after various times of culture in medium alone or with the addition of IL-10 ( $10 \mathrm{ng} /$ $\mathrm{ml})$. Unseparated B cells and large splenic $B$ cells (GCC) exhibit an enhanced viability in the presence of IL-10 (closed symbols) as compared with that observed in medium (open symbols). One representative experiment out of three is illustrated.

were performed on B cells separated according to their density. Uncultured small B cells expressed bcl-2 protein (Fig. $2 C$ ), whereas large cells displayed no bcl-2 protein (Fig. $2 \mathrm{D}$ ), as expected from previous studies $(10,12)$. However, when cultured in the presence of r-IL-10, large spleen B cells expressed the bcl-2 protein (Fig. $2 E$ ) during $7 \mathrm{~d}$ of observation. The synthesis of bcl-2 protein by small B cells was unmodified by $r$-IL-10. The data were confirmed in a more quantitative way by FACS ${ }^{\circledR}$ analysis. The level of bcl-2 in GCC treated with IL-10 appears similar to or even higher than that of freshly separated small B cells (Fig. 3, $A$ and $C$ ). No significant expression of bcl-2 was observed for GCC cultured in medium alone (Fig. $3 B$ ).

IL-10-dependent upregulation of bcl-2 protein by $I L-2$ and $I L-4$. In view of these results, we investigated whether other lymphokines could also induce bcl- 2 protein expression in GCC. A fraction ( 30\%) of large splenic B cells cultured with IL-2 $(50 \mathrm{U} / \mathrm{ml})$ or IL-4 $(100 \mathrm{U} / \mathrm{ml})$ but not IL-6 $(1 \mathrm{ng} / \mathrm{ml})$ expressed the bcl-2 protein at day 2 (Fig. 2, $F$ and $G$ ); however, bcl-2 synthesis was only transient and was no longer detectable at day 7 . Interestingly, in the presence of anti-IL-10 mAb, IL2- or IL-4-induced expression of the bcl-2 protein was abolished (Fig. $2 H$ ), suggesting that IL-10 was responsible for this upregulation of the bcl-2 expression.

\section{Discussion}

Antibody responses to $T$ cell-dependent antigens occur mainly in peripheral lymphoid organs. Germinal center architecture provides a unique environment for recruitment of B cells that display somatically mutated membrane Ig after binding to their antigen on the follicular dendritic cells (11). This process is highly selective; only B cells with high affinity receptors survive, whereas most other antigen-driven $B$ cells kill themselves by apoptosis. Cell death can be rescued in vitro by immobilized antibody to surface Ig, soluble mAb to CD40, or soluble CD23 and IL-1 $\alpha(10,13)$. All of these stimuli prevent GCC from entering apoptosis by inducing expression of bcl-2 protein (10).

We show here that IL-10 is one additional and crucial factor involved in prolonged cell survival. Indeed, IL-10 enhanced purified splenic B cell survival during a 15-d culture period. This increased viability was most striking when separated GCC were studied, since the latter cells undergo apoptosis after a 



Figure 2. IL-10 enhances bcl-2 protein expression by splenic B cells. Bcl-2 expression was studied by immunofluorescence at various times of in vitro culture in medium alone or with the addition of various lymphokines. At day 2, a fraction of unseparated splenic B cells expressed bcl-2 $(A)$, whereas in the presence of IL-10 most B cells displayed a bright staining $(B)$. In uncultured splenic B cells, bcl-2 was detected in small B cells $(C)$, but was absent from large cells $(D)$. Most large B cells expressed bcl-2 protein when cultured with IL-10 $(E)$. A subset of large B cells displayed bcl-2 in the presence of IL-2 $(F)$ or IL-4 $(G)$. Anti-IL-10 antibodies prevented IL-4-induced bcl-2 expression $(H)$. 


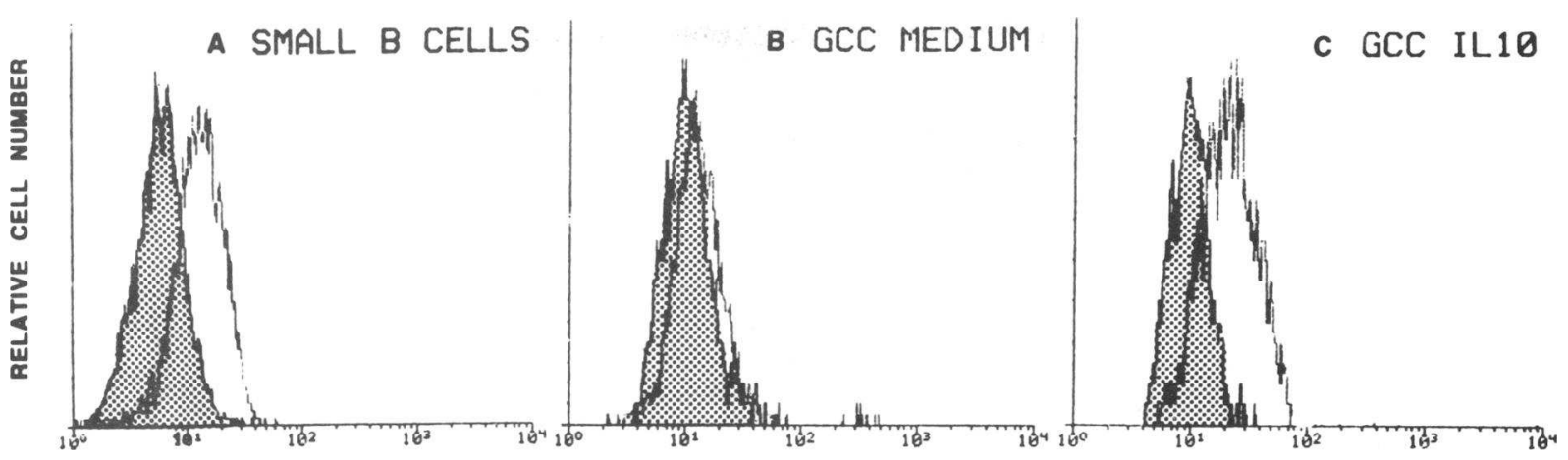

Figure 3. Expression of bcl-2 protein in splenic B cells by flow cytometric analysis. Cells were stained with anti-bcl-2 or unrelated control mAbs ( shaded histogram) as detailed in Methods; $(A)$ Small splenic B cells express constitutively the bcl-2 protein; $(B)$ Viable GCC cultured in medium for $3 \mathrm{~d}$ display no significant staining, whereas $(C)$ GCC cultured with IL-10 express a high level of bcl-2 protein.

brief in vitro culture. This effect was associated with the induction of bcl-2 protein expression as shown by fluorescence analysis from days 2-7 of unseparated or large splenic (GCC) B cells cultured in the presence of IL-10 (Figs. 2 and 3 ).

Altogether, these results suggest that IL-10 is a potent factor able to rescue GCC from apoptosis by inducing the synthesis of the bcl-2 protein. The bcl-2 protooncogene encodes a $25-\mathrm{kD}$ protein that is localized to the inner mitochondrial membrane (14). Bcl-2 prolongs cell survival by blocking programmed cell death (15). In normal tissues, the bcl-2 protein expression is topographically confined to the long-lived recirculating B cells from the follicular mantle and is absent from the centroblasts and centrocytes destined to die (10-12). Similarly, surviving $T$ cells within the medulla of the thymus express substantial bcl-2 protein, while those in the cortex are devoid of bcl-2 (12). The transfection of the bcl-2 gene in interleukin-dependent hematopoietic cell lines induces their survival when deprived of growth factors $(14,16)$. Bcl-2-Ig transgenic mice show a polyclonal increase in small IgM/IgD B cells because of extended survival $(17,18)$, and a fraction of these animals go on to develop follicular lymphomas (19). In human pathology, inappropriate expression of the bcl- 2 oncogene due to its translocation to the IgH locus has been implicated in the pathogenesis of follicular center cells lymphoma (20).

Further experiments were performed here to investigate whether the control of bcl-2 expression could be mediated by lymphokines other than IL-10. We found that IL-2 and IL-4 (but not IL-6) induced a transient expression of bcl-2 that was detectable in a fraction of GCC cells at day 2. Interestingly, addition of anti-IL-10 antibodies abolished this effect, suggesting that IL-10 was responsible for this upregulation of bcl-2 expression. Of note, it was shown that IL-1, IL-2, IL-3, IL-4, IL-5, IL-6, IL-7, and interferon $\alpha$ or $\gamma$ have no protective effect on GCC apoptosis (11). On the other hand, it was recently reported that IL- 4 rescues B cells from patients with chronic lymphocytic leukemia from apoptosis via a bcl-2-dependent pathway (21).

What can be the physiological source of IL-10 in lymphoid follicles in vivo? Human CD4 cells as well as monocytes may provide this cytokine (22). Normal human activated B cells as well as malignant B cells $(23,24)$ are also able to synthesize IL-10. Indeed, we found that Cowan I Staphylococcus aureusactivated large splenic B cells displayed an intracytoplasmic staining using an anti-IL-10 mAb, indicating that stimulated GCC B cells may produce their own IL-10 (data not shown).
Therefore, the upregulation of the bcl-2 protein expression induced by these stimuli would be dependent of an IL-10-dependent autocrine pathway.

The role of IL-10 in human pathology deserves careful examination. Persistent or abnormally high production of IL-10 may play a role in the development of follicular lymphomas lacking bcl-2 gene rearrangement $(25,26)$ or may be indirectly responsible for autoimmune diseases since prolonged B cell survival in bcl-2 transgenic mice favors the production of autoantibodies (27).

\section{References}

1. Fiorentino, D. F., M. W. Bond, and T. R. Mosmann. 1989. Two types of mouse T helper cell. IV. Th2 clones secrete a factor that inhibits cytokine production by Thl clones. J. Exp. Med. 170:2081-2095.

2. Fiorentino, D. F., A. Zlotnik, P. Vieira, T. R. Mosmann, M. Howard, K. W. Moore, and A. O'Garra. 1991. IL-10 acts on the antigen presenting cell to inhibit cytokine production by Thl cells. J. Immunol. 146:3444-3451.

3. de Waal Malefyt, R., J. Abrams, B. Bennett, C. G. Figdor, and J. E. de Vries. 1991. Interleukin 10 (IL-10) inhibits cytokine synthesis by human monocytes. An autoregulatory role of IL-10 produced by monocytes. J. Exp. Med. 174:12091220.

4. de Waal Malefyt, R., J. Haanen, H. Spits, M.-G. Roncarolo, A. te Velde, C. Figdor, K. Johnson, R. Kastelein, H. Yssel, and J. E. de Vries. 1991. Interleukin 10 (IL-10) and viral IL-10 strongly reduce antigen-specific human T cell proliferation by diminishing the antigen-presenting capacity of monocytes via downregulation of class II major histocompatibility complex expression. J. Exp. Med. 174:915-924.

5. Thompson-Snipes, L., V. Dhar, M. W. Bond, T. R. Mosmann, K. W. Moore, and D. M. Rennick. 1991. Interleukin 10. A novel stimulatory factor for mast cells and their progenitors. J. Exp. Med. 173:507-510.

6. MacNeil, I. A., T. Suda, K. W. Moore, T. R. Mosmann, and A. Zlotnik. 1990. IL-10, a novel growth cofactor for mature and immature T cells. J. Immunol. 145:4167-4173.

7. Chen, W. F., and A. Zlotnik. 1991. IL-10: a novel cytotoxic T cell differentiation factor. J. Immunol. 147:528-534.

8. Go, N. F., B. E. Castle, R. Barrett, R. Kastelein, W. Dang, T. R. Mosmann, K. W. Moore, and M. Howard. 1990. Interleukin 10, a novel B cell stimulatory factor. Unresponsiveness of X chromosome-linked immunodeficiency B cells. $J$. Exp. Med. 172:1625-1631.

9. Rousset, F., E. Garcia, T. Defrance, C. Péronne, N. Vezzio, D.-H. Hsu, R. Kastelein, K. W. Moore, and J. Banchereau. 1992. Interleukin 10 is a potent growth and differentiation factor for activated human B lymphocytes. Proc. Natl. Acad. Sci. USA. 89:1890-1893.

10. Liu, Y. J., D. Y. Mason, G. D. Johnson, S. Abbot, C. D. Gregory, D. L. Hardie, J. Gordon, and I. C. MacLennan. 1991. Germinal center cells express bcl-2 protein after activation by signals which prevent their entry into apoptosis. Eur. J. Immunol. 21:1905-1910.

11. Liu, Y. J., D. E. Joshua, G. T. Williams, C. A. Smith, J. Gordon, and I. C. MacLennan. 1989. Mechanism of antigen-driven selection in germinal centres. Nature (Lond.). 342:929-931.

12. Hockenbery, D., M. Zutter, W. Hickey, M. Nahm, and S. J. Korsmeyer. 1991. Bcl-2 protein is topographically restricted in tissues characterized by apoptotic cell death. Proc. Natl. Acad. Sci. USA. 88:6961-6965. 
13. Liu, Y. J., J. A. Cairns, M. J. Holder, S. D. Abbot, K. U. Jansen, J. Y. Bonnefoy, J. Gordon, and I. C. MacLennan. 1991. Recombinant 25-kDa CD23 and interleukin $1 \alpha$ promote the survival of germinal center B cells: evidence for bifurcation in the development of centrocytes rescued from apoptosis. Eur. J. Immunol. 21:1107-1114.

14. Hockenbery, D., G. Nunez, C. Millman, R. D. Schreiber, and S. J. Korsmeyer. 1990. Bcl-2 is an inner mitochondrial membrane protein that blocks programmed cell death. Nature (Lond.). 348:334-336.

15. Korsmeyer, S. J. 1992. Bcl-2 initiates a new category of oncogenes: regulators of cell death. Blood 80:879-886.

16. Nunez, G., L. London, D. Hockenbery, M. Alexander, J. McKearn, and S. J. Korsmeyer. 1990. Deregulated Bcl-2 gene expression selectively prolongs survival of growth factor-deprived hemopoietic cell lines. J. Immunol. 144:36023610.

17. McDonnell, T. J., N. Deane, F. M. Platt, G. Nunez, U. Jaeger, J. P. McKearn, and S. J. Korsmeyer. 1989. Bcl-2-immunoglobulin transgenic mice demonstrate extended B cell survival and follicular lymphoproliferation. Cell 57:79-88

18. McDonnell, T. J., G. Nunez, F. M. Platt, D. Hockenbery, L. London, J. P. McKearn, and S. J. Korsmeyer. 1990. Deregulated Bcl-2-immunoglobulin transgene expands a resting but responsive immunoglobulin $\mathrm{M}$ and D-expression Bcell population. Mol. Cell. Biol. 10:1901-1907.

19. McDonnell, T. J., and S. J. Korsmeyer. 1991. Progression from lymphoid hyperplasia to high-grade malignant lymphoma in mice transgenic for the t(14;18). Nature (Lond.). 349:254-256.
20. Tsujimoto, Y., J. Gorham, J. Cossman, E. Jaffe, and C. M. Croce. 1985. The $\mathrm{t}(14 ; 18)$ chromosome translocations involved in B-cell neoplasms result from mistakes in VDJ joining. Science (Wash. DC). 229:1390-1393.

21. Dancescu, M., M. Rubio-Trujillo, G. Biron, D. Bron, G. Delespesse, and M. Sarfati. 1992. Interleukin 4 protects chronic lymphocytic leukemic B cells from death by apoptosis and upregulates Bcl-2 expression. J. Exp. Med. 176:1319-1326.

22. Butch, A. W., G.-Y. Chung, J. W. Hoffmann, and M. H. Nahm. 1993. Cytokine expression by germinal center cells. J. Immunol. 150:39-47.

23. Burdin, N., C. Péronne, J. Banchereau, and F. Rousset. 1993. EpsteinBarr virus transformation induces B lymphocytes to produce human interleukin 10. J. Exp. Med. 177:295-304.

24. Emilie, D., R. Touitou, M. Raphael, M. Peuchmaur, O. Devergnee, D Rea, J. Coumbraras, M. C. Crevon, L. Edelman, I. Joab, and P. Galanaud. 1992. In vivo production of interleukin-10 by malignant cells in AIDS lymphomas. Eur. J. Immunol. 22:2937-2942.

25. Pezzella, F., A. G. Tse, J. L. Cordell, K. A. Pulford, K. C. Gatter, and D. Y. Mason. 1990. Expression of the Bcl-2 oncogene protein is not specific for the 14:18 chromosomal translocation. Am. J. Pathol. 137:225-232.

26. Zutter, M., D. Hockenbery, G. A. Silverman, and S. J. Korsmeyer. 1991. Immunolocalization of the bcl-2 protein within hematopoietic neoplasms. Blood 78:1062-1068.

27. Strasser, A., S. Whittingham, D. L. Vaux, M. L. Bath, J. M. Adam, S Cory, and A. W. Harris. 1991. Enforced BCL2 expression in B-lymphoid cells prolongs antibody responses and elicits autoimmune disease. Proc. Natl. Acad. Sci. USA. 88:8661-8665. 